\title{
Adaptivní bruslení
}

\section{Adaptive Ice Skating}

\section{Gabriela Žilková Hrázská}

Fakulta sportovních studií Masarykovy univerzity, Brno

\begin{abstract}
Abstrakt
Př́spěvek se zabývá problematikou adaptivního bruslení určeného osobám se zdravotním postižením. Představuje zdravotní prínosy adaptivního bruslení, organizace, které zavádějí programy adaptivního bruslení a asistenční produkty vhodné pro samotný výcvik. Jsou zmínèny základní charakteristiky bruslar̆ského výcviku zdravotně postižených a některá jeho specifika.
\end{abstract}

\begin{abstract}
The article deals adaptive ice skating for people with healtly disabilities. The work presents the health benefits of adaptive ice skating, some of the organizations that carry adaptive ice skating programs, as well as assistive products suitable for the training. Also there are discussed the basic characteristics of training of disabled and highlighted some of its specifics.
\end{abstract}

Klíčová slova: Adaptivní bruslení, zdravotní postižení, bruslařský výcvik, asistenční produkty pro výcvik adaptivního bruslení.

Key words: $\quad$ Adaptive skating, healtly disability, skating practice, assistive products suitable for the adaptive skating.

\section{Úvod}

Pohybové aktivity a sport osob se zdravotním postižením napomáhají zejména společenské integraci, rozvoji volních vlastností, posilování sebedůvěry, význam mají rovněž pro výchovu $\mathrm{k}$ samostatnosti a soběstačnosti. Vhodně zvolené pohybové aktivity často přispívají i ke kompenzaci zdravotních omezení. Sport zdravotně postižených je integrální součástí sportovního prostředí a je prováděn jak organizovaně, tak individuálně, a to na všech úrovních (sport pro všechny, výkonnostní a vrcholový sport). Většina sportovních odvětví je provozována v souladu s mezinárodními standardy a jsou členěna do kategorií podle druhu postižení.

K méně rozšířenému sportovnímu odvětví, zejména pak v České republice, patří bruslení postižených, které je určeno všem zájemcům, jejichž fyzická zdatnost je určitým způsobem omezena, a to bud' dočasně, nebo trvale. $\mathrm{V}$ anglosaských zemích, které jsou v provozování této činnosti nejdále, se často užívá názvu adaptive skating (adaptivní bruslení) nebo therapeutic skating (terapeutické neboli léčebné bruslení). V tomto textu užíváme termín adaptivní bruslení.

\section{Zdravotní přínos adaptivního bruslení}

Adaptivnímu bruslení se mohou se souhlasem ošetřujícího lékaře věnovat zájemci s celou řadou zdravotních postižení, např́ílad osoby s mentálním postižením (např. Downův syndrom), se stavy po mozkové obrně, se zrakovým, sluchových či tělesným postižením (např. pooperační stavy kyčelního kloubu, amputace), dále osoby s epileptickým nebo srdečním onemocněním, s psychickými problémy, zotavující se z drogových závislostí apod. Odborníci z řad zdravotníků a sportovních činovníkủ jsou názoru, že pod dohledem je bruslení vhodnou sportovní aktivitou pro rehabilitaci mnoha typů zdravotního postižení. Důležité je pochopení povahy zdravotního omezení, stejně jako znalost konkrétních cvičení, která jsou pro osoby s daným zdravotním postižením přínosná. 
Bylo zjištěno, že bruslení přispívá k lepšímu dýchání, zlepšení krevního oběhu, rovnováhy, držení těla, vytrvalosti a celkové síly. Kromě toho je adaptivní bruslení možností k překonání omezení vyplývajících ze znevýhodnění a př́ijemnou rehabilitací prostřednictvím zdravého cvičení. Právě adaptivní bruslení s vhodným rehabilitačním programem doporučuje stále více lékařů pacientům zotavujícím se z nehod, infarktů a jiných onemocnění. Zájemci tak mají rovněž možnost poznat nové přátele se společným zájmem a identifikovat se se skupinou.

Hodnocením př́nosnosti adaptivního bruslení pro děti se zdravotním postižením se věnoval v roce 2009 i výzkum nemocnice Franciscan Hospital for Children v americkém Brightonu. Program adaptivního bruslení navržený dětskými terapeuty absolvovalo dvaadvacet dětí se zdravotním postižením ve věku od pěti do dvanácti let, které se účastnily jednou týdně speciálního bruslařského výcviku v délce šesti týdnů. $V$ hodnocení výzkumu byl brán zřetel především na účast probandů $\mathrm{v}$ rámci výzkumu, výskyt úrazů, získané bruslařské dovednosti i hodnocení programu ze strany samotného dítěte, jeho rodičů a instruktora bruslařského výcviku. Připravený program adaptivního bruslení se pro zdravotně postižené ukázal jako vhodný a je autory výzkumu doporučován.

\section{Organizace věnující se adaptivnímu bruslení}

V anglosaských zemích funguje několik organizací, jejichž posláním je sdružování osob se zdravotním postižením, které mají zájem věnovat se adaptivnímu bruslení. Jednou z nich je nezisková organizace Bruslařské sdružení pro nevidomé a zdravotně postižené (SABAH), která byla založena již v roce 1977 $\mathrm{v}$ Buffalu. V současnosti SABAH provozuje programy pro bruslaře všech věkových kategorií.

Další z organizací, která poskytuje osobám se zdravotním postižením příležitost ke zvýšení jejich osobního potenciálu prostřednictvím rozvoje bruslařských dovedností, je americká organizace Gliding Stars (v překladu Klouzající hvězdy). Byla založena v roce 1994 bývalou krasobruslařkou Elizabeth M. O`Donnellovou a věnuje se poskytování a zlepšování rozsáhlého programu adaptivního bruslení. Organizace se v průběhu let dostala do povědomí mnoha lidí, kteří vyjádřili zájem o zahájení podobného programu také ve svých vlastních komunitách, čímž se postupně rozrůstala. V současné době se skládá z národní centrály, dvou produktových společností a sedmi místních poboček, které poskytují instruktážní programy na ledě pro členy mnoha komunit, kteří se musí vyrovnávat s různými fyzickými a mentálními postiženími. Pobočky jsou řízeny koordinátory za pomoci mnoha dobrovolníků, speciálně vyškolených instruktorů na ledě a komunity dárců, jejichž finanční prostředky slouží pro úspěšný rozvoj a provoz místního adaptivního bruslařského programu. Pobočky tak poskytují nejen instrukce a zkušenosti, ale i specializované asistenční produkty potřebné pro adaptivní bruslařský výcvik. Na celkový provoz organizace stále dohlíží její zakladatelka Elizabeth O’Donnellová, která je i autorkou školicích materiálů použitých v programu Gliding Stars.

Programy adaptivního bruslení se zabývají i organizace Special Olympics, které jsou vedle anglosaských k dispozici i v jiných zemích, například v Rakousku. Poskytují př́ležitost osobám se zdravotním postižením, zejména však pro osoby s mentálním postižením. V rámci organizací Special Olympics jsou pořádány i bruslařské soutěže, $\mathrm{z}$ nichž některé jsou určeny pro závod v rychlosti, jiné pro předvedení bruslařských pohybů v souladu s hudbou. Soutěže se řídí speciálním mezinárodním sportovním programem vytvořeným organizací Special Olympics na základě pravidel Mezinárodní bruslařské unie (ISU). Tzv. krasobruslařské soutěže se pořádají ve třech bruslařských disciplínách - jednotlivci, sportovní dvojice a tance na ledě - rozdělených dále dle stupňủ obtížnosti. Právě jednotlivé stupně obtížnosti jsou rozhodující pro náplň požadovaných prvků dvou bruslařských soutěžních programů, jejichž výsledky mají vliv na celkový výsledek soutěžícího jednotlivce nebo páru v závodě.

\section{Asistenční produkty pro adaptivní bruslení}

Pro adaptivní bruslení je doporučeno využívat speciálně navržené a vyráběné asistenční produkty, které bruslařům se zdravotním postižením usnadní pohyb na ledě. Asistenční produkty jako chodítka „learn-toskate“, berle s bruslemi nebo speciálně upravené boty s bruslemi poskytují i lidem s mnoha typy zdravotních postižení možnost poznat kouzlo bruslení, a to i těm, kteří mají problémy při stání nebo chủzi. 
Na podporu stability a rovnováhy na ledě byly pro bruslaře se zdravotním postižením vyvinuty podle zakladatelky Gliding Stars O’Donnellové tř̌i modely chodítek, které jsou na zakázku vyráběny ve Spojených státech. První model chodítka (obr. 1) mohou využívat jak začínající zdraví bruslaři, tak i bruslaři se zdravotními problémy. K dispozici jsou tři velikosti chodítek, pokrývající všechny věkové kategorie bruslařů. Druhý model je určen pro bruslaře, kteří jsou schopni chůze, prŕípadně dokáží nést váhu těla po omezenou dobu, avšak potřebují při bruslení pomoci s udržením správného držení. Př́kladem mohou být bruslaři s dětskou mozkovou obrnou nebo rozštěpem páteře. Chodítko jim poskytuje možnost odpočinku, přičemž stále zůstávají na ledě. K dispozici jsou v rámci tohoto modelu dvě velikosti a každé chodítko je nastavitelné do několika výšek. Třetí model chodítka je určen pro bruslaře, kteři mají omezenou nebo nulovou schopnost nést svou váhu těla. Pomocí závěsného sedadla s nastavitelnými popruhy, které pomáhají zůstat ve vzpřímené poloze na bruslích, mohou i přes své zdravotní omezení poznat pohyb po ledě.

Rovněž speciálně navržené boty s bruslemi pro adaptivní bruslení (obr. 2) jsou k dostání ve třech modelech a byly vyvinuty ve spolupráci Elizabeth O'Donnellové se známým americkým výrobcem klasických krasobruslařských bot Riedell Shoe Company. Jednotlivé modely jsou rozděleny dle specifických problémů, se kterými se lze při adaptivním bruslení setkat. Lidé, kteří nosí kotníkovou ortézu (AFO) nebo supramaleolarní ortézu (SMO), musí mít speciální bruslařskou obuv, která při nošení toto zařízení pojme. Stejně tak lidé s Downovým syndromem nebo chirurgicky upravenýma nohama potřebují mnohem širší bruslařskou obuv, která se svým tvarem přizbůsobí obrysům nohy. Upravené boty s bruslemi poskytují bruslařum nejen pohodlí, ale i důležitou podporu při bruslařském pohybu. Všechny modely určené pro adaptivní bruslení jsou dostupné v mnoha velikostech pro děti i dospělé.

Kromě zmíněných asistenčních produktů jsou zájemcům o adaptivní bruslení pro jejich bezpečnost doporučovány rovněž přilby, podpůrné postroje a další podobné pomůcky.

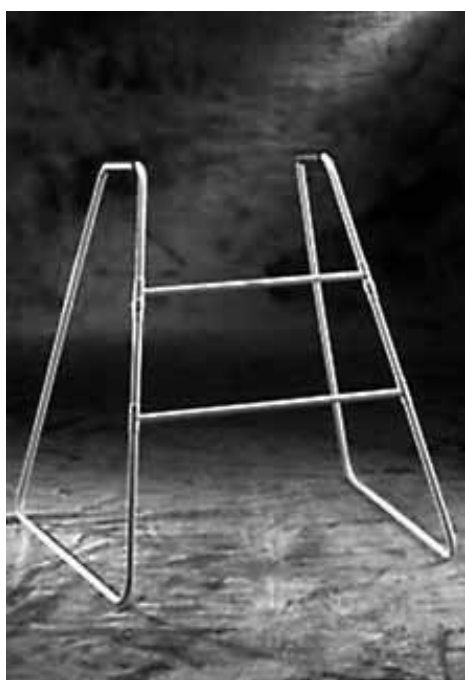

Obr. 1 - Chodítko pro bruslaře (www.glidingstars.org)

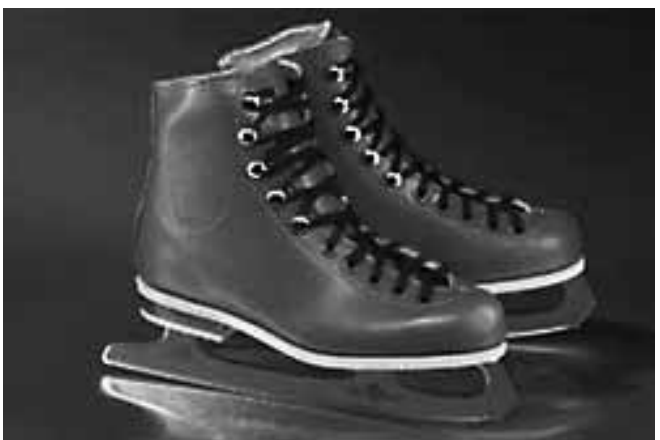

Obr. 2 - Boty s bruslemi speciálně navržené pro adaptivní bruslení (www.glidingstars.org)

\section{Výcvik adaptivního bruslení}

Na zajištění výcviku v programu adaptivního bruslení spolupracuje mnoho zúčastněných osob: provozní zimního stadionu, ošetřující lékaři, rodiče, speciálně školení instruktoři, terapeuti a další dobrovolníci. Všichni musí být s programem adaptivního bruslení seznámeni a ochotni se dále učit, jak se vypořádat s požadavky a individuálními možnostmi handicapovaných osob. Pro instruktory bruslení je to př́iležitost, jak rozšířit své pedagogické schopnosti o výuku osob s určitým zdravotním postižením. 
Poté, co jsou účastníci zapsáni do programu adaptivního bruslení, je nutné ve spolupráci instruktora a lékaře určit, co daný účastník může nebo nemůže provádět v rámci výcviku s ohledem na své postižení. $\mathrm{Na}$ základě toho je potřeba určit, zda bruslař vyžaduje individuální př́istup k výcviku, či mu bude lépe vyhovovat skupinový výcvik. Každý bruslař by měl být rovněž na začátku výcviku seznámem s pravidly bezpečného pohybu na ledě.

Základem výcviku je nácvik správného postoje na bruslích, který se začínají bruslaři s instruktorem učit mimo ledovou plochu. Rovněž je důležité bruslařům vysvětlit a demonstrovat, jakým způsobem se po ledě pohybovat, jak se otáčet, i to, jak při bruslení padat. Při prvním vstupu na ledovou plochu by měl mít každý bruslař svého pomocníka, který jej přidržuje v podpaží a pomáhá mu překonat prvotní strach. V žádném prrípadě by instruktoři neměli své žáky $\mathrm{k}$ bruslení nutit, nevyvíjet na ně tlak a nepřivádět je tak do stresu. Pokud žáci chtějí během výcviku opustit ledovou plochu, mělo by jim to být umožněno.

Jak již bylo řečeno, je nezbytné, aby instruktoři dostatečně pochopili zdravotní postižení svých žáků, omezení podmínek, a přizpůsobili se jejich konkrétním potřebám. Například u bruslařu s tělesným a kombinovaným postižením je nutno dbát na zajištění podpory (obr. 3). Nevidomí bruslaři by měli být vždy na začátku výcviku informovaní o použití vytyčovacích sloupků kolem kluziště, rovněž musí být orientováni do směru jízdy slovem nebo dotykem, přičemž je důležité, aby se v daném směru nevyskytovaly žádné nečekané překážky. Vhodné je rovněž připojení Bell-systému při vstupu a výstupu z prostoru ledové plochy. Neslyšícím žákům je pro změnu nutné nahradit slovní instrukce gesty a pohyby, pokud ovládá instruktor znakovou řeč, výcvik to velmi ulehčí. Vizuální signál dokonce dovoluje neslyšícím bruslařům udržet při bruslení rytmus hudby. Vždy je tedy nutné najít takový komunikační systém, který je vhodný pro jejich potřeby.

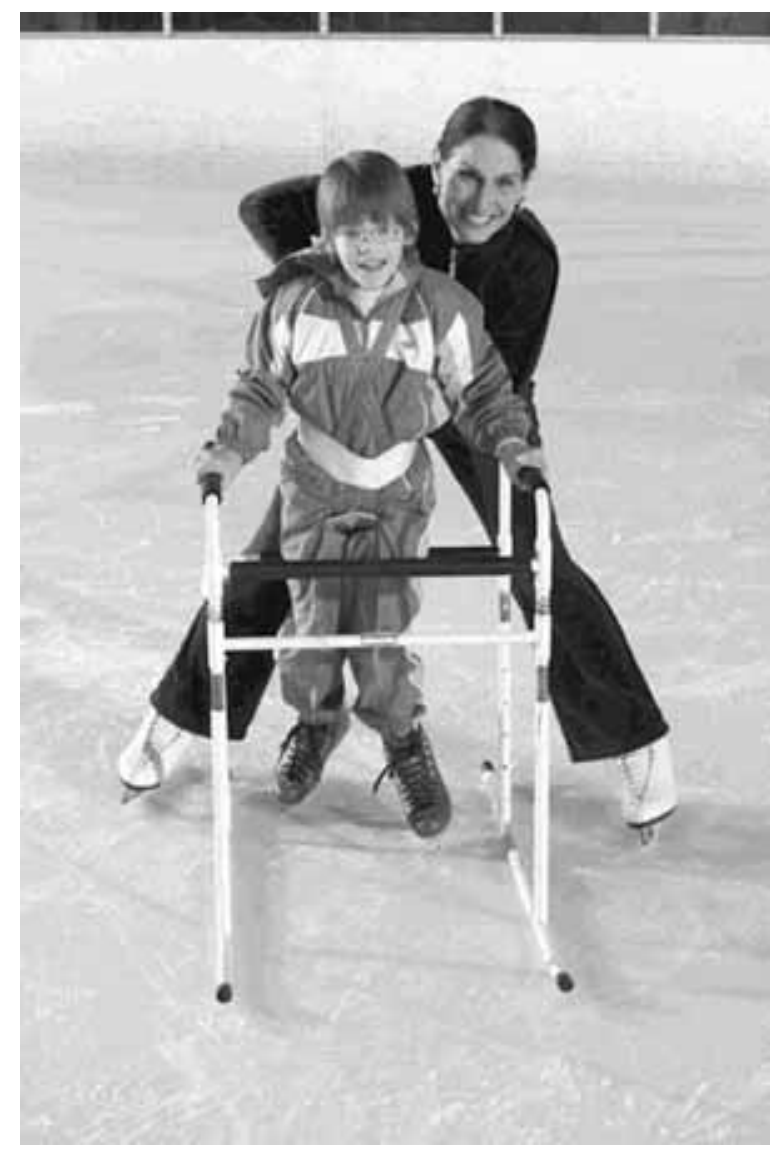

Obr. 3 - Výcvik v rámci programu adaptivního bruslení (www.glidingstars.org) 
Doporučuje se, aby instruktoři vedli poznámky o výcviku každého bruslaře, zaznamenávali informace o způsobu přístupu $\mathrm{k}$ bruslařům, evidovali doporučení jejich ošetřujících lékařů apod. Evidenci je vhodné doplnit i záznamy o pokroku v rámci výcviku, např́iklad ve formě videozáznamů. Vždy je př́inosné, aby instruktor motivoval bruslaře k stanovení realistických cílů. Většině zdravotně postižených bruslařů však bude odepřena možnost naučit se složitější dovednosti, nebot tomu neodpovídá jejich zdravotní stav.

Kromě nácviku základních bruslařských dovedností by měly být pro odlehčení zařazovány i jednoduché hry na ledě, ovšem vždy s ohledem na možnosti postižených bruslařů. Většina z organizací zabývajících se adaptivním bruslením pořádá pro své žáky na závěr výcvikového kurzu jednoduchou soutěž nebo veřejné představení $\mathrm{v}$ duchu lední revue. Bruslaři jsou tak v průběhu sezóny motivování $\mathrm{k}$ nácviku veřejného vystoupení, při němž pak mají možnost předvést své dovednosti a zažít vzrušující atmosféru. Pokročilí bruslaři se mohou zúčastnit oficiálních bruslařských soutěží, např. Special Olympics.

\section{Závěr}

Stat pojednává o adaptivním bruslení na základě cizojazyčných materiálů zejména $\mathrm{z}$ anglosaských zemí. V České republice v současnosti neexistuje žádná organizace, která by sdružovala postižené sportovce věnující se tomuto sportovnímu odvětví, jehož součástí jsou i soutěže. Byly uvedeny zdravotní př́nosy adaptivního bruslení pro osoby se zdravotním postižením, představeny některé z organizací, které se věnují programům adaptivního bruslení i asistenční pomůcky vhodné pro samotný výcvik. Zmínili jsme základní charakteristiky bruslařského výcviku a upozornili na některá specifika jeho vedení, která přináší konkrétní zdravotní postižení bruslařu.

\section{Literatura}

Evaluation of an adaptive ice skating programme for children with disabilities. Dostupné na WWW: < www.ncbi.nlm.nih.gov/pubmed/19842821 >.

Gliding Stars, Inc. Adaptive Ice Skating Programs: Dostupné na WWW: < www.glidingstars.org > Gliding Stars, Inc. Adaptive Products: Dostupné na WWW: < http://glidingstars.org/adaptive.html > Koncepce státní podpory sportu v ČR č.j.: 20099/2009-5 ke dni 17.9. 2009. Dostupné na WWW: < http:// www.msmt.cz/file/8267_1_1/download/ >

Sabah, Inc. Dostupné na WWW: < www.sabahinc.org >

Special Olympics: Dostupné na WWW: < www.specialolympics.org >

Special Olympics - Figure Skating Rules. Dostupné na WWW: < http://media.specialolympics.org/soi/ files/sports/Figure\%20Skating-Rules-2010_.pdf >

United Cerebral Palsy - Life without limits for people with disabilities. Dostupné na WWW: < www.ucp. org > 